Litteratur

. Samdal GB, Meland E. Er det overvekt eller vektfokus som er helseskadelig? Tidsskr Nor Legeforen 2014: 134: 2247-8.

2. Campos P. Saguy A, Ernsberger $P$ et al. The epidemiology of overweight and obesity: public health crisis or moral panic? Int J Epidemiol 2006; 35: 55-60. 3. Rigby N. The epidemiology of overweight and obesity: Commentary: counter point to Campos et al. Int J Epidemiol 2006: 35: 79-80, discussion 81-2.

4. Kim S. Popkin BM. Commentary: understanding the epidemiology of overweight and obesity-a real global public health concern. Int J Epidemiol 2006; 35: 60-7. discussion $81-2$

5. Stevens J, McClain JE, Truesdale KP. Commentary: obesity claims and controversies. Int J Epidemiol 2006: 35: 77-8, discussion 81-2.

6. Flegal KM, Kit BK, Orpana $\mathrm{H}$ et al. Association of all-cause mortality with overweight and obesity using standard body mass index categories: a systematic review and meta-analysis. JAMA 2013; 309: 71-82

7. Tobias DK, Hu FB. Does being overweight really reduce mortality? Obesity (Silver Spring) 2013; 21: 1746-9.

\section{E. Meland \& G.B. Samdal svarer:}

Vi takker Alexander Wahba for nyttig kommentar og påminnelse om vitenskapelig redelighet og balansert siteringspraksis. De som interesserer seg for hvordan «krigen mot fedme» ble en akseptert folkehelsestrategi gjennom selektiv forskningsformidling, «viral spredning» av motemeninger og allianser mellom akademi og slanke- og medisinalindustri, finner nyttig stoff $i$ boken The end of the obesity epidemic (1). Wahba forsøker å gi inntrykk av at de sju kommentarartiklene til Campos (2) var samstemmige i sin kritikk. Det var de ikke. I kommentarene finner man støtte for Campos' tvil på den epidemiologiske evidensen om helsefarene ved overvekt, en enda sterkere kritikk av vektfokus som folkehelsestrategi, og også bekreftelser på samrøre mellom akademi og industrielle interesser.

Wahba forsøker også å diskreditere våre kilder som feilaktige ved at de ikke gjør rede for konfundering og bias. Den litteraturen han selv siterer, gjør rede for og justerer for noen av disse faktorene, men ikke for andre. Denne diskusjonen tror vi er nytteløs fordi observasjonsevidens alltid vil være en kilde til feilslutninger i medisinen. Det vi vet fra eksperimentell evidens, er følgende: Slanking fører til mindre insidens av type 2 diabetes, men dette oppnås også ved økt fysisk aktivitet (3). Slanking fører til reduksjon av risikofaktorer knyttet til metabolsk syndrom, men påvirker ikke sykelighet og dødelighet (4). Sykelighet og dødelighet reduseres ved økt fysisk aktivitet, men dette er først og fremst dokumentert i postinfarktstudier (5). Et sunt og allsidig Middelhavskosthold reduserer sykelighet og dødelighet både i primær- og sekundærprofylakse $(6,7)$. Intervensjoner basert på kroppsaksept og intuitiv spising fører til et sunnere kroppsbilde og et mer naturlig forhold til mat (8).

Wahba mener også at akademiet er uten ansvar for samfunnets kroppsfokus og diskriminering av overvektige medmennesker. Leserne kan selv bedømme hvordan årets «Obesity summit» $\mathrm{i}$ London spiller på kroppsforakt ved å ta en titt på deres nettsider (9). Det er også dokumentert eksperimentelt at måten forskningsresultater formidles i media stimulerer til diskriminering og fordommer (10). Forskere er medansvarlige for hvordan forskningsresultater formidles i samfunnet (11). Vi mener vi har solid vitenskapelig dokumentasjon for å anbefale helsemyndighetene, akademiet og den kliniske medisinen å fremme selvaksept, matglede, bevegelsesglede og mellommenneskelig aksept for kropper i alle fasonger som grunnlag for folkehelsearbeidet.

\section{Eivind Meland \\ eivind.meland@igs.uib.no \\ Gro Beate Samdal}

Eivind Meland (f. 1950) er spesialist i allmennmedisin, fastlege og professor ved Universitetet i Bergen

Ingen oppgitte interessekonflikter.

Gro Beate Samdal (f. 1958) er sykepleier og ph.d.-stipendiat ved Universitetet i Bergen.

Ingen oppgitte interessekonflikter
Litteratur

1. Gard M. The end of the obesity epidemic. New York: Routledge; 2011

2. Campos P, Saguy A, Ernsberger $P$ et al. The epidemiology of overweight and obesity: public health crisis or moral panic? Int J Epidemiol 2006: 35: 55-60.

3. Tuomilehto J, Lindström J, Eriksson JG et al; Finnish Diabetes Prevention Study Group. Prevention of type 2 diabetes mellitus by changes in lifestyle among subjects with impaired glucose tolerance. N Engl J Med 2001; 344: 1343-50.

4. Wing RR, Bolin P, Brancati FL et al; Look AHEAD Research Group. Cardiovascular effects of intensive lifestyle intervention in type 2 diabetes. N Engl J Med 2013; 369: 145-54

5. Jolliffe JA, Rees K, Taylor RS et al. Exercise-based rehabilitation for coronary heart disease. Cochrane Libr 2003.

6. de Lorgeril M. Salen P. Martin J-L et al. Mediterranean diet, traditional risk factors, and the rate of cardiovascular complications after myocardial infarction: final report of the Lyon Diet Heart Study. Circulation 1999; 99: 779-85.

7. Estruch R, Ros E, Salas-Salvadó J et al; PREDIMED Study Investigators. Primary prevention of cardiovascular disease with a Mediterranean diet. N Engl J Med 2013; 368: 1279-90.

8. Bacon L, Aphramor L. Weight science: evaluating the evidence for a paradigm shift. Nutr J 2011; 10: 9

9. The 2015 Obesity Summit: www.regonline.co.uk/builder/site/ Default.aspx?EventID=1538135 (10.01. 2015)

10. Saguy AC, Frederick D, Gruys K. Reporting risk, producing prejudice: how news reporting on obesity shapes attitudes about health risk, policy, and prejudice. Soc Sci Med 2014; 111: 125-33

11. Forssén A, Meland E, Hetlevik I et al. Rethinking scientific responsibility. J Med Ethics 2011: 37: 299-302

\section{Re: En integrert forståelse av subjektive lidelser $\mathrm{i}$ klinisk praksis}

Debatten etter Tveråmos og medarbeideres kronikk har så langt avvist en dikotomiserende språkbruk om subjektivitet og objektivitet i omtale av helseplager (1). Jeg går videre med en konstruktiv kritikk av kronikkens helse- og sykdomsbegreper.

Det er bra at artikkelen definerer sykdom med utgangspunkt $i$ et helsebegrep: «Helse kan betraktes som et overskudd, og sykdom kan forstås som et underskudd av ressurser i forhold til hverdagens krav». Men definisjonene her er meget vage. Hvilke ressurser er det mer spesifisert tale om? Jeg synes filosofen Lennart Nordenfelts helseteori har mye for seg (2). Den utnevner evner, mål/verdier (kronikken skriver også om mål og verdier mot slutten) og anstendige omgivelsesmessige forhold (relasjonelt, sosialt strukturelt, naturmessig og kulturelt) som sentrale helsefaktorer. De synes vel anvendelige i praksis (3).

Jeg er enig med Nordenfelt om at vi trenger begrepet uhelse som et mellomledd mellom helse og sykdom. Med ordet uhelse kan vi omtale underskudd av helseressurser som et selvstendig fenomen (4). Tveråmo og medarbeidere anvender ikke et slikt begrep. Dermed defineres underskudd av ressurser i seg selv som sykdom. Dette fører til et alt for omfattende sykdomsbegrep. Nordenfelt definerer sykdom i stedet som en kroppslig og/eller mental prosess som er slik at den tenderer til å redusere individets helse. Det er redusert helse eller helseplager som pasienten vanligvis oppsøker legen for. Det medisinske spørsmålet er om det kan påvises årsaker til redusert helse, årsaker som er funnet også hos andre med tilsvarende redusert helse $(2,4)$. Spørsmålet kan utvides til om det finnes begrunnede hypoteser om hva som kan være årsaker til en sykdomsprosess. Det må her anvendes et årsaksbegrep som tar høyde for at en kompleks organisme består av enkeltelementer av anatomisk, biokjemisk og fysiologisk slag. Elementenes egenskaper bestemmes dessuten i stor grad av interaksjon med andre elementer, ikke minst i omgivelsene. Interaksjonene kan også ha kausal kraft. Dessuten må det anerkjennes at komplekse biologiske helheter har kapasitet til å skape subjektiv opplevelse, kanskje med nye kausale egenskaper.

Det er vanskelig å formulere biopsykososial tenkning på en konsistent måte. Det viktigste er at vi forsøker overfor pasientene. Det er dessuten viktig å beskrive gode kliniske metoder som Tveråmo og medarbeidere også gjør. 
Hans Magnus Solli (f. 1948) er dr. med. og trygdemedisinsk forsker ved Klinikk psykisk helse og rusbehandling, Sykehuset i Vestfold. Ingen oppgitte interessekonflikter.

\section{Litteratur}

1. Tveråmo A, Johnsen IB, Meland E. En integrert forståelse av subjektive lidelser i klinisk praksis. Tidsskr Nor Legeforen 2014; 134: 2174-6.

2. Nordenfelt $L$. The concepts of health and illness revisited. Med Health Care Philos 2007; 10: 5-10.

3. Solli HM, Barbosa da Silva A, Egeland J. Usefulness of an ability-based health model in work ability assessments provided by psychiatrists and psychology specialists writing social security certificates. Disabil Rehabil 2014; Jul 2: 1-8. epub ahead of print.

4. Solli HM. Evnebaserte helse- og sykdomsbegreper i NAV-systemet. Tidsskr Nor Legeforen 2011; 131: 1097-9.

\section{Re: En integrert forståelse av subjektive lidelser i klinisk praksis}

Tveråmo og medarbeidere foreslår å kombinere den biopsykososiale modellen fra Engel og teorier om homøostase og allostase med stress- og mestringsteorier (1). Ved hjelp av gode illustrasjoner vil de vise hvordan medisinen bedre kan favne forsømte flekker på lidelsens kart. Kronikken er et spenstig og spennende bidrag, selv om lite er nytt. Teorier om helse som balanse og sykdom som ubalanse går tilbake til hippokratikerne (2). Sykdom forstått som reaksjon på stress eller stimuli var godt kjent blant annet i 1795 (3), og helse som margin er glimrende beskrevet av legen og filosofen George Canguilhem (4). Biologiske, mentale, og sosiale perspektiver på sykdom er godt forankret i eksisterende sykdomsteorier (2). Det som gjør bidraget interessant, er forsøket på å kombinere ulike tankesett til en helhetlig teori om helse og sykdom.

Tillat meg kort å kommentere noen av utfordringene ved tilnærmingen. For det første gir kronikken oss ikke bedre innsikt i pasienters subjektive opplevelse av lidelse. Det skyldes nok at forfatterne er opptatt av årsakene til at lidelsen vedvarer. Men med sin modell står de $\mathrm{i}$ fare for å se homøostase, allostase og «narrative skript» der pasienten opplever smerte, fortvilelse, skam og svikt. Bringer det oss nærmere pasienters lidelse? Erstatter man ikke laboratoriesvar og røntgenbilder med nye abstraksjoner? For det andre, baserer den integrerte modellen seg på en (ny) reduksjonistisk forståelsesramme. Gir det en mer helhetlig forståelse av menneskets lidelse eller forsøker man å fange subjektive lidelser med objektive teorier? For det tredje, reiser modellen spørsmål om menneskets autonomi. Siden identitet og lidelse forklares ut fra fysiske, mentale og sosiale forhold, kan man undre seg over om det er plass til et bestemmende selv.

Tveråmo og medarbeidere oppfordrer riktignok leger til å interessere seg for pasientenes verdier og plagsomme tanker, symptomer og handlinger som «hjelper eller hindrer dem $\mathrm{i}$ å nå sine mål i livet»(1). Men her møter vi en fjerde utfordring: Hvor langt skal leger gå i å hjelpe pasienter med å nå sine mål i livet? Hvor dypt skal man grave i deres «narrative skript»? Hvor går medisinens grenser mot det personlige og det sosiale? Integrerer man så mye at man favner alt og evner intet?

Alle disse spørsmålene kan Tveråmo og medarbeidere selvsagt ikke svare på i en kort kronikk. Jeg håper de utvikler modellen. Medisinen trenger å utvide sine forståelsesrammer, men også å se sin egen begrensning.

\section{Bjørn Hofmann}

b.m.hofmann@medisin.uio.no

Bjørn Hofmann (f. 1964) er forsker ved The Dartmouth Institute for Health Policy and Clinical Practice.

Ingen oppgitte interessekonflikter.

\footnotetext{
Litteratur

1. Tveråmo A, Johnsen IB, Meland E. En integrert forståelse av subjektive lidelser i klinisk praksis. Tidsskr Nor Legeforen 2014; 134: 2174-6.

2. Hofmann B. Hva er sykdom? Oslo: Gyldendal Akademisk, 2014
}

3. Hufeland CW. Ideen über Pathogenie und Einfluss der Lebenskraft auf Entstehung und Form der Krankheiten. Jena: In der Academischen Buchhandlung, 1795. 4. Canguilhem G. The Normal and the Pathological. New York: Zone Books, 1949/ 1991.

\section{E. Meland og medarbeidere svarer:}

Hans Magnus Solli og Bjørn Hofmann kommer med svært konstruktiv kritikk av vår kronikk om subjektive lidelser i Tidsskriftet nr. 22/2014 (1). Vi er enige $i$ at en todeling mellom helse og sykdom kan innebære inflasjon i sykdomsbegrepet. Vi beskrev dette som et kontinuum, og synes Nordenfelts begrep om «uhelse» som et mellomstadium kan være en akseptabel måte å illustrere dette på. Solli anerkjenner det som var kronikkens hovedintensjon: Et perspektiv som kan ha større behandlingsmessig og samfunnsmedisinsk relevans enn eksisterende diagnostiske merkelapper.

Bjørn Hofmann introduserer fire hovedutfordringer for oss. For det første er han redd for at homøostase, allostase og narrativt skript blir nye objektiverende og fremmedgjørende kategorier for lidende mennesker med subjekterfaringer som ikke kommer til orde. Vi påstår ikke at vårt perspektiv er det eneste. Vi tror at det kan gi større relevans i det kliniske møtet enn dagens diagnostiske forvirring og ofte kontraproduktive rådgivning. Vi har som intensjon å gjøre pasientens biografi og narrativ mer sentralt i pasientmøtet, og derved bemyndige pasienten og legen til å utvikle mer helsefremmende narrative skript.

Vi må gi Hofmann rett i hans andre utfordring: Vi forsøker å fange subjektive erfaringer i nye objektiverende kategorier. Vi er ikke fenomenologiske totalindividualister. Vi prøver å fremme en diagnostisk og behandlingsmessig praksis med plass til individets historie, men tror at det er felles trekk ved slike historier som ofte handler om kronisk stress og manglende mestringsevne. Dette er ingen deterministisk modell. Vi tar utgangspunkt $i$ at legen og pasienten kan skape større rom for selvbestemmelse, personlig vekst, mestring og læring.

Hofmann utfordrer oss i en påstand om at å interessere seg for pasientens verdier og mål med livet, representerer grenseløs graving i pasientens privatsfære og narrative skript. All medisinsk praksis er truet av å havne i én av to grøfter: det tekniske og instrumentelle overgrep på den ene siden, og det sentimentale og stakkarsliggjørende overgrep på den andre. Vi må utvikle praksis og beredskap mot begge disse utskeielser i medisinen. Hvis den nye sykdomsbølgen handler om meningstap, krenkelser og maktesløshet, er det malplassert ikke å vise interesse for slike sider ved pasientens livsverden.

Solli har rett i at det ikke er enkelt å fremstille hva det biopsykososiale perspektiv i medisinen handler om. Engel la i et intervju med Tidsskriftet vekt på gjensidig språklig interesse. Han avviste at hans bidrag åpnet for grenseløshet. «Det dreier seg om å forstå pasientens perspektiv, men også å sette pasienten i stand til å løse sine problemer», uttalte han (2).

\section{Eivind Meland \\ eivind.meland@igs.uib.no \\ Aksel Tveråmo}

Ine Baug Johnsen

Eivind Meland (f. 1950) er spesialist i allmennmedisin, fastlege og professor ved Institutt for global helse og samfunnsmedisin, Universitetet i Bergen.

Ingen oppgitte interessekonflikter.

Aksel Tveråmo (f. 1963) er spesialist i allmennmedisin og fastlege i Bergen.

Ingen oppgitte interessekonflikter.

Ine Baug Johnsen (f. 1966) er psykolog og driver egen praksis ved Nevropsykologisk Helsetjeneste, Paradis.

Ingen oppgitte interessekonflikter. 